\title{
ANALISIS PENGARUH BIAYA PENDIDIKAN TERHADAP PENINGKATAN ASET DAN LABA PADA PERBANKAN SYARIAH DI INDONESIA
}

\author{
Ridwansyah \\ Sekolah Tinggi Ilmu Ekonomi (STIE) Lampung \\ Email:ridwansyahxanda@yahoo.co.id
}

\begin{abstract}
One of the key to maintaining the quality of Syariah pious performance of BUS or UUS and BPRS is to develop and educate employees to maintain superior quality of human resources as well as ready and able to become the locomotive of syariah banking development in Indonesia. Training and development activities provide dividends to employees and companies, in the form of skills and skills that will further be a valuable asset for the company. This study aims to determine how much influence the cost of education to increase the number of assets and profits derived by Islamic banking in Indonesia both BUS, UUS and BPRS. The method used in this research is quantitative method by using secondary data in the form of report of educational cost level and increasing amount of assets and profit in BUS or UUS and BPRS in Indonesia during 2009-2013 period. For the data analysis process this research uses simple linear regression analysis, and hypothesis t test with educational cost in BUS or UUS and SRB as independent variable (X) and total assets and profit in BUS or UUS and BPRS as dependent variable (Y). Looking at the results of statistical tests using SPSS tools can be seen that the cost of education does not affect the amount and amount of assets and profits owned by BUS or UUS and BPRS in Indonesia.
\end{abstract}

Keywords: Cost of education, assets, profit, Shariah bank

\begin{abstract}
Abstrak: Salah satu kunci untuk menjaga kualitas kinerja pebankan syariah baik BUS atau UUS dan BPRS adalah dengan mengembangkan dan mendidik karyawan untuk menjaga kualitas SDM yang unggul serta siap dan mampu menjadi lokomotif pengembangan perbankan syariah di Indonesia. Kegiatan pelatihan dan pengembangan memberikan dividen kepada karyawan dan perusahaan, berupa keahlian dan keterampilan yang selanjutnya akan menjadi aset yang berharga bagi perusahaan. Penelitian ini bertujuan untuk mengetahui seberapa besar pengaruh biaya pendidikan terhadap peningkatan jumlah aset dan laba yang diperoleh perbankan syariah di Indonesia baik BUS,UUS maupun BPRS. Metode yang digunakan dalam penelitian ini adalah metode kuantitatif dengan menggunakan data skunder berupa laporan tingkat biaya pendidikan dan peningkatan jumlah aset dan laba di BUS atau UUS dan BPRS di Indonesia selama periode 2009-2013. Untuk proses analisis data penelitian ini menggunakan analisis regresi linear sederhana, dan uji hipotesis t dengan biaya pendidikan di BUS atau UUS dan BPRS sebagai variabel independen (X) serta jumlah aset dan laba di BUS atau UUS dan BPRS sebagai variabel dependen (Y). Melihat pada hasil uji statistik dengan menggunakan alat bantu SPSS dapat dilihat bahwa biaya pendidikan tidak berpengaruh pada besar dan jumlah aset dan laba yang dimiliki oleh BUS atau UUS dan BPRS di Indonesia.
\end{abstract}

Keywords: Biaya pendidikan, aset, laba, bank syariah 


\section{PENDAHULUAN}

Seperti kita ketahui perbankan merupakan salah satu agen pembangunan (agent of development) dalam kehidupan bernegara, karena fungsi utama dari perbankan adalah sebagai lembaga intermediasi keuangan (financial intermediary institution), yaitu lembaga yang menghimpun dana dari masyarakat dalam bentuk simpanan dan menyalurkannya kembali kepada masyarakat dalam bentuk kredit atau pembiayaan. Fungsi yang demikian juga yang menjadi concern dari perbankan syariah di samping fungsi lain sebagai lembaga penyedia jasa lalu lintas keuangan.

Tumbuh kembang perbankan syariah di Indonesia mengalami perkembangan yang cukup signifikan seperti dalam keterangan yang dilansir dari (Statistik Perbankan Syariah, Bank Indonesia, 2015) menyatakan bahwa perkembangan perbankan syariah dari tahun 2010 - 2015 bermula pada tahun 2010 dari 6 Bank Umum Syariah (BUS), 25 Unit Usaha Syariah (UUS) dan 138 Bank Pembiayaan Rakyat Syariah (BPRS) hingga pada tahun 2015 berkembang menjadi 11 Bank Umum Syariah (BUS), 22 Unit Usaha Syariah (UUS) dan 163 Bank Pembiayaan Rakyat Syariah (BPRS).

Perkembangan perbankan syariah di Indonesia pada khususnya juga diperkuat dengan adanya dukungan dari pemerintah, yang bisa kita lihat dengan adanya kepastian dari sisi regulasi, yakni adanya Undang-Undang Nomor 10 Tahun 1998 tentang Perubahan Atas Undang-Undang Nomor 7 Tahun 1992 tentang Perbankan yang lebih mengakomodasi dan memberi peluang bagi perkembangan perbankan syariah. Kehadiran undang-undang tersebut diperkuat lagi dengan lahirnya Undang-undang Nomor 21 tahun 2008 tentang Perbankan Syariah dikatakan bahwa perbankan syariah merupakan perbankan yang kegiatanya berdasarkan prinsip syariah atau hukum islam dan secara tegas mengakui eksistensi dari perbankan syariah dan membedakannya dengan sistem perbankan konvensional.

Pesatnya Perkembangan perbankan syariah di Indonesia selama 6 tahun terakhir dan tetap terjangannya kinerja perbankan syariah walaupun dalam kondisi krisis ekonomi menunjukan bahwa keberadaan perbankan syariah di Indonesia patut menjadi perhatian penting bagi seluruh masyarakat Indoensia untuk mempertimbangakan industri keuangan yang akan digunakanya. Pangsa pasar Perbankan Syariah pun terus tumbuh yang didukung oleh populasi muslim terbesar yang dimiliki Indonesia. Hal tersebut menunjukkan bahwa permintaan terhadap produk jasa keuangan syariah di Indonesia sangat besar.

Daya tarik utama dari industri perbankan syariah adalah penerapan nilai etika dan moral dalam kegiatan perbankan. Perbedaan yang paling banyak diketahui oleh masyarakat adalah penghapusan sistem bunga dan penerapan sistem bagi hasil dalam pembagian keuntungan kepada nasabah, yang meminimalisasi risiko perbankan ketika kondisi ekonomi sedang melemah maupun krisis. Masih banyak keunggulan maupun karakteristik perbankan syariah yang menarik dan penting untuk dibahas, apalagi melihat regulasi perbankan syariah yang selalu berubah dan berkembang sepanjang waktu.

Salah satu kunci untuk menjaga kinerja perbankan syariah dan mempertahankan masyarakat Indonesia untuk tetap menjadi nasabah perbankan syariah adalah dengan melaksanakan program pendidikan dan pelatihan bagi seluruh sumber daya manusia (SDM) yang ada dilingkungan perbankan syariah, sehingga SDM tersebut mampu memberikan pelayanan yang baik dan maksimal kepada nasabah dan pada akhirnya akan meningkatkan penilaian terhadap kinerja perbankan tersebut. 
Kinerja perusahaan termasuk didalamnya adalah perbankan syariah merupakan sesuatu yang dihasilkan oleh suatu perusahaan dalam periode tertentu dengan mengacu pada standar yang ditetapkan. Kinerja perusahaan merupakan hasil yang dapat diukur dan menggambarkan kondisi empirik suatu perusahaan dari berbagai ukuran yang disepakati. Untuk mengetahui kinerja yang dicapai maka dilakukan penilaian kinerja. Penilaian suatu kinerja dapat dilihat dari 2 sisi, yakni sisi keuangan (kuantitatif) maupun non keuangan (kualitatif) berdasarkan pada Peraturan Bank Indonesia Nomor 9/PBI/2007 tanggal 4 Desember 2007 tentang Sistem Penilaian Tingkat Kesehatan Bank Umum Berdasarkan Prinsip Syariah (BUS) (tanggal 24 Januari 2007 tentang Sistem Penilaian Tingkat Kesehatan Bank Umum Berdasarkan Prinsip Syariah (Lembaran Negara Republik Indonesia Tahun 2007 Nomor 31, Tambahan Lembaran NegaraRepublik Indonesia Nomor 4699), dijelaskan bahwa Penilaian kuantitatif adalah penilaian terhadap posisi, perkembangan maupun proyeksi rasio-rasio keuangan Bank dan UUS, sedangkan penilaian kualitatif adalah penilaian terhadap faktor-faktor yang mendukung hasil Penilaian Kuantitatif, penerapan manajemen risiko, dan kepatuhan Bank atau UUS.

Dalam penelitian ini penulis lebih memfokuskan pada penilaian terhadap pengaruh dari alokasi biaya pendidikan terhadap peningkatan aset dan laba pada perbankan syariah di Indonesia.

Berdasarkan uraian latar belakang yang telah dikemukakan sebelumnya, maka yang menjadi rumusan masalah dalam penelitian ini adalah: Berapa besar pengaruh alokasi biaya pendidikan terhadap peningkatan Aset dan Laba pada Bank Umum Syariah (BUS), Unit Usaha Syariah (UUS) dan Bank Pembiayaan Rakyat Syariah (BPRS) di Indonesia?

\section{KAJIAN TEORI}

Pelatihan Dan Pengembangan SDM. Penggunaan istilah pelatihan (training) dan pengembangna (Development) dikemukaan para ahli, yaitu dale yoder menggunakan istilah pelatihan untuk pegawai pelaksana dan pengawas. Sedangkan istilah pengembangan ditujukan untuk pegawai tingkat manajemen.

Pengembangan lebih difokuskan pada penigkatan kemampuan dalam pengambilan keputusan dan memperluas hubungan manusia (human relation) bagi manajemen tingkat atas dan menengah, sedangkan pelatihan dimaksudkan utnuk pegawai tingkat bawah (pelaksana). Pengembangan merupakan suatu proses jangka panjang uang mempergunakan prosedur sistematis dan terorganisisr dimana pegwai managerial mempelajari penngetahuan konseptual dan teoritis guna mencapai tujuan yang umum.

Dengan demikian istilah pelatihan ditujukan kepada pegawai pelaksanan dalam rangka meningkatkan pengetahuan dan keterampilan teknis, sedangkan pengembangan diperuntukan bagi pegawai tingkat manajerial dalam rangka meningkatkan kemampuan konseptual, kemampuan dalam dalam pengambilan keputusan, dan memperluan human relation.

Kegiatan pelatihan dan pengembangan memberikan dividen kepada karyawan dan perusahaan, berupa keahlian dan keterampilan yang selanjutnya akan menjadi aset yang berharga bagi perusahaan. Melalui pelatihan karyawan akan bertambah kemampuanya dan demikian pula bagi perusahaan, yaitu dalam rangka memenuhi tuntutan para manajer dan departemen SDM. Namun, kegiatan pelatihan dan pengembangan bukan solusi universal yang dapat memenuhi semua kebutuhan. Rancangan tugas yang efektif, pemilihan/seleksi, penempatan dan kegiatan-kegiatan lainya adalah juga diperlukan. 
Tujuan atau sasaran dari pelatihan dan pengembangan pada dasarnya dapat dikembangkan dari serangkaian pertanyaan sebagai berikut: (1) Keefektifan / validitas pelatihan. Apakah peserta memperoleh keahlian, pengetahuan dan kemampuan selama pelatihan; (2) Keefektifan pengalihan/transfer ilmu pengetahuan. Apakah pengetahuan, keahlian atau kemampuan yang dipelajari dalam pelatihan dapat meningkatkan kinerja dalam melakukan tugas; (3) Keefektifan/validitas intraorganisasional. Apakah kinerja pekerjaan dari grup baru yang menjalani program pelatihan di perusahaan yang sama dapat dibandingkan dengan kinerja pekerjaan dari grup sebelumnya; (4) Keefektifan/validitas interorganisasional. Dapatkah suatu program pelatihan yang diterapkan di satu perusahaan berhasil di perusahaan yang lain.

Tujuan dari pelatihan dan pengembangan adalah: (a) untuk meningkatkan kuantitas output; (b) untuk meningkatkan kualitas output; (c) untuk menurunkan biaya limbah dan perawatan; (d) untuk menurunkan jumlah dan biaya terjadinya kecelakaan; (e) untuk menutunkan jumlah turnover, ketidakhadiran kerja serta meningkatkan kepuasan kerja; (f) untuk mencegah timbulnya antipati karyawan.

Manfaat pelatihan dan Pengembangan: Pertama. Manfaat untuk karyawan: (a) Membantu karyawan dalam membuat keputusan dan pemecahan masalah yang lebih efektif; (b) Melalui pelatihan dan pengembangan, variabel pengenalan, pencapaian prestasi, pertumbuhan, tanggung jawab dan kemajuan dapat diinternalisasi dan dilaksanakan; (c) Membantu mendorong dan mencapai pengembangan diri dan rasa percaya diri; (d) Membantu karyawan mengatasi stres, tekanan, frustasi, dan konflik; (e) Memberikan informasi tentang meningkatnya pengetahuan kepemimpinan, keterampilan komunikasi dan sikap; (f) Meningkatkan kepuasan kerja dan pengakuan; (g) Membantu karyawan mendekati tujuan pribadi sementara meningkatkan keterampilan interaksi; (h) Memnuhi kebutuhan personal peserta dan pelatihan; (i) Memberikan nasihat dan jalan untuk pertumbuhan masa depan; (j) Membangun rasa pertumbuhan dalam pelatihan; (k) Membantu pengembangan keterampilan mendengar, bicara dan menulis dengan latihan; (1) Membantu menghilangkan rasa takut melaksanakan tugas baru.

Kedua. Manfaat untuk perusahaan: (a) mengarahkan untuk meningkatkan profitabilitas atau sikap yang lebih positif terhadap orientasi profit; (b) memperbaiki pengetahuan kerja dan keahlian pada semua level perusahaan; (c) memperbaiki moral SDM; (d) membantu karyawan untuk mengetahui tujuan perusahaan; (e) membantu menciptakan image perusahaan yang lebih baik; (f) mendukung otentisitas, keterbukaan dan kepercayaan; (g) meningkatkan hubungan antara atasan dan bawahan; (h) Membantu pengembangan perusahaan; (i) belajar dari peserta; (j) membantu mempersiapkan dan melaksanakan kebijakan perusahaan; $(\mathrm{k})$ memberikan informasi tentang kebutuhan perusahaan di masa depan; (l) perusahaan dapat membuat keputusan dan memecahkan masalah yang lebih efektif; (m) membantu pengembangan promosi dari dalam; (n) Membantu pengembangan keterampilan kepmimpinan, motivasi, kesetiaan, sikap dan aspek lain yang biasanya diperlihatkan pekerja; (o) membantu meningkatkan efesiensi, efektivitas, produktivitas dan kualitas kerja; (p) Membantu menekan biaya dalam berbagai bidang seperti produksi, SDM, administrasi; (q) meningkatkan rasa tanggung jawab terhadap kompetensi dan pengatahuan perusahaan; (r) Meningkatkan hubungan antar buruh dengan manajemen; (s) mengurangi biaya konsultan luar dengna menggunakan konsultan internal; (t) Mendorong mengurangi perilaku merugikan; (u) menciptakan iklim yang baik untuk pertumbuhan; (v) Membantu meningkatkan komunikasi organisasi; (w) Membantu karyawan untuk 
menyesuaikan diri dengan perubahan; (x) Membantu menangani konflik sehingga terhindar dari stres dan tekanan kerja.

Kinerja. Kinerja menurut Caves mengungkapkan bahwa kinerja yaitu penilaian bagaimana hasil ekonomi dari kegiatan industri memberikan kemungkinan kontribusi terbaik guna mencapai tujuan. Dari pendapat tersebut di atas dapat didefinisikan bahwa kinerja adalah seberapa baik hasil yang dicapai oleh perusahaan dalam mencapai tujuan perekonomian, dimana tujuan perekonomian adalah untuk memaksimumkan kesejahteraan ekonomi.

Kinerja keuangan perusahaan merupakan hasil dari banyak keputusan individual yang dibuat secara terus menerus oleh manajemen. Oleh karena itu, untuk menilai kinerja keuangan suatu perusahaan, perlu dilibatkan analisa dampak keuangan kumulatif dan ekonomi dari keputusan dan mempertimbangkanya dengan menggunakan ukuran komparatif. Dalam membahas metode penilaian kinerja keuangan perusahaan harus didasarkan pada data keuangan yang dipublikasikan yang dibuat sesuai dengan prinsip akuntansi keuangan yang berlaku umum.

Berdasarkan pendapat diatas, penulis menyimpulkan bahwa kinerja keuangan adalah pengukuran atas kegiatan operasional perusahaan yang digunakan untuk menilai sejauh mana tujuan perusahaan bisa tercapai.

Ada dua bentuk kinerja, yaitu kinerja operasional dan kinerja keuangan. Kinerja operasional lebih menekankan kepada kepentingan pihak internal perusahaan seperti Kota atau divisi yang diukur dengan menggunakan kecepatan dan kedisiplinan. Sedangkan kinerja keuangan biasanya diukur menggunakan rasio-rasio keuangan yang dilihat dari laporan keuangan perusahaan tersebut.

Kinerja keuangan perusahaan termasuk didalamnya adalah perbankan syariah dan lembaga keuangan syariah lainya, dapat dilihat dan diukur dengan sistem penilaian kesehatan bank. Terkait dengan penelitian ini maka penialaian tingkat kesehatan dilakukan pada Bank Umum Syariah (BUS). Dimana salah satu indikator kesehatanya akan menjadi indikator kinerja BUS tersebut pula.

Berdasarkan pada Peraturan Bank Indonesia Nomor 9/PBI/2007 tanggal 4 Desember 2007 tentang Sistem Penilaian Tingkat Kesehatan Bank Umum Berdasarkan Prinsip Syariah (BUS) (tanggal 24 Januari 2007 tentang Sistem Penilaian Tingkat Kesehatan Bank Umum Berdasarkan Prinsip Syariah (Lembaran Negara Republik Indonesia Tahun 2007 Nomor 31, Tambahan Lembaran NegaraRepublik Indonesia Nomor 4699) disebutkan bahwa penilaian terhadap tingkat kesehatan Bank Umum Syariah adalah terhadap faktorfaktor berikut: (a) Permodalan (capital); (b) kualitas aset (asset quality); (c) manajemen (management); (d) rentabilitas (earning); (e) likuiditas (liquidity); dan (f) sensitivitas terhadap risiko pasar (sensitivity to market risk).

Dalam penelitian ini penulis lebih memfokuskan pada faktor kualitas aset dan rentabilitas, dimana akan dinilai bagaimana aset dan laba dapat dihasilkan.

\section{METODE}

Pendekatan Penelitian. Pendekatan yang digunakan dalam penelitian ini adalah pendekatan kuantitatif, pendekatan kuantitatif adalah suatu penelitian yang dimaksud untuk menilai seberapa besar pengaruh alokasi biaya pendidikan terhadap peningkatan jumlah aset dan laba. 
Ruang Lingkup Penelitian. Mengacu pada latar belakang dan rumusan masalah yang telah disebutkan sebelumnya penelitian ini terbatas hanya pada Bank Umum Syariah (BUS) dan tidak meneliti lebih jauh mengenai Unit Usaha Syariah (UUS) maupun Bank Pembiayaan Rakyat Syariah (BPRS) namun penelitian ini mencakup seluruh BUS yang ada di Indoensia.

Jenis dan Sumber Data. Jenis data yang digunakan dalam penelitian ini adalah data sekunder berupa laporan dan data tingkat pertumbuhan aset, laba dan biayaa pendidikan di perbankan syariah di Indonesia yang bersumber dari data skunder diolah.

Teknik Analisis Data. Metode analisis data dalam penelitian ini menggunakan analisis regresi linear sederhana, regresi merupakan teknik statistik (alat analisis) hubungan yang digunakan untuk meramalkan atau memperkirakan dari satu vaariabel dalam hubunganya dengan variabel yang lain melalui persamaan garis regresi. Analisis regresi bisa berupa garis lurus (linear) dan non linear. Sementara analisis regresi pada penelitian ini adalah analisis regresi linear sederhana, yaitu regresi yang hanya melibatkan dua variabel yaitu variabel bebas $(\mathrm{X})$ dan satu variabel terikat $(\mathrm{Y})$, dimana variabel $(\mathrm{X})$ dalam penelitian ini adalah biaya pendidikan dan variabel (Y1) adalah Aset, dan variabel (Y2) adalah Laba.

\section{HASIL DAN PEMBAHASAN}

\section{Hasil Analisis}

Tabel 1. data Dana Pendidikan Pada BUS dan BPRS di Indonesia selama lima tahun $(2009-2013)$

\begin{tabular}{llllll}
\hline Besar Dana Pendidikan & 2009 & 2010 & 2011 & 2012 & 2013 \\
\hline BUS \& UUS & $40,6 \%$ & $33 \%$ & $-8 \%$ & $116 \%$ & $30 \%$ \\
BPRS & $32,8 \%$ & $30 \%$ & $39 \%$ & $35 \%$ & $31 \%$ \\
\hline
\end{tabular}

Sumber: Data Sekunder diolah

Tabel 2. Aset pada BUS dan BPRS di Indonesia selama lima tahun (2009 - 2013)

\begin{tabular}{llllll}
\hline Aset & 2009 & 2010 & 2011 & 2012 & 2013 \\
\hline BUS dan UUS & $33,4 \%$ & $48 \%$ & $49 \%$ & $34 \%$ & $24 \%$ \\
BPRS & $25,4 \%$ & $29 \%$ & $29 \%$ & $33 \%$ & $24 \%$ \\
\hline
\end{tabular}

Sumber: Data Skunder diolah

Tabel 3. Laba pada BUS dan BPRS di Indonesia selama lima tahun (2009 - 2013)

\begin{tabular}{llllll}
\hline Laba & 2009 & 2010 & 2011 & 2012 & 2013 \\
\hline BUS dan UUS & $76,4 \%$ & $34 \%$ & $43 \%$ & $67 \%$ & $31 \%$ \\
BPRS & $83,2 \%$ & $29 \%$ & $23 \%$ & $23 \%$ & $21 \%$ \\
\hline
\end{tabular}

Sumber: Data Skunder diolah

Untuk melihat seberapa besar pengaruh variabel independen (X) terhadap variabel dependent (Y) atau dalam penelitian ini adalah melihat seberapa besar pengaruh 
pembiayaan Dana Pendidikan terhadap Aset dan Laba BUS dan BPRS di Indonesia, penulis menggunakan uji hipotesis sebagai berikut:

1. Dana Pendidikan Pada BUS dan UUS terhadap Aset pada BUS dan UUS diperoleh hasil sebagai berikut:

Pengaruh dana pendidikan pada BUS dan UUS terhadap aset, berdasarkan perhitungan statistik, diperoleh hasil persamaan sebesar 0,594, ini menunjukan bahwa korelasi antara Dana Pendidikan dengan perolehan laba pada BUS dan UUS mempunyai hubungan yang cukup kuat. Hasil pengolahan data dengan Uji t diperoleh sebesar 1,278. Jika dibandingkan dengan $t$ tabel 2,3536 sehingga dapat disimpulkan bahwa tidak terdapat pengaruh yang signifikan antara dana pendidikan dengan tingkat perolehan laba pada BUS dan UUS.

2. Dana Pendidikan Pada BUS dan UUS terhadap Laba Pada BUS dan UUS diperoleh hasil sebagai berikut:

Pengaruh dana pendidikan pada BUS dan UUS terhadap aset, berdasarkan perhitungan statistik, diperoleh hasil persamaan sebesar 0,264, ini menunjukan bahwa korelasi antara Dana Pendidikan dengan perolehan laba pada BUS dan UUS mempunyai hubungan yang lemah. Hasil pengolahan data dengan Uji t diperoleh sebesar -4,74. Jika dibandingkan dengan $\mathrm{t}$ tabel 2,3536 sehingga dapat disimpulkan bahwa tidak terdapat pengaruh yang signifikan antara dana pendidikan dengan jumlah aset yang dimiliki pada BUS dan UUS.

3. Dana Pendidikan Pada BPRS terhadap Aset pada BPRS diperoleh hasil sebagai berikut: Pengaruh dana pendidikan pada BPRS terhadap laba, berdasarkan perhitungan statistik, diperoleh hasil persamaan sebesar 0,16, ini menunjukan bahwa korelasi antara Dana Pendidikan dengan perolehan laba pada BPRS mempunyai hubungan yang lemah. Hasil pengolahan data dengan Uji t diperoleh sebesar -2,85. Jika dibandingkan dengan $t$ tabel 2,3536 sehingga dapat disimpulkan bahwa tidak terdapat pengaruh yang signifikan antara dana pendidikan dengan jumlah laba yang dimiliki pada BPRS.

4. Dana Pendidikan Pada BPRS terhadap Aset pada BPRS diperoleh hasil sebagai berikut: Pengaruh dana pendidikan pada BPRS terhadap aset, berdasarkan perhitungan statistik, diperoleh hasil persamaan sebesar 0,421, ini menunjukan bahwa korelasi antara Dana Pendidikan dengan aset pada BPRS mempunyai hubungan yang lemah. Hasil pengolahan data dengan Uji t diperoleh sebesar 0,804. Jika dibandingkan dengan t tabel 2,3536 sehingga dapat disimpulkan bahwa tidak terdapat pengaruh yang signifikan antara dana pendidikan dengan jumlah aset yang dimiliki pada BPRS.

Pembahasan. Beradasarkan hasil pengolahan data yang telah disebutkan sebelumnya diperoleh hasil yang sama yakni tidak berpengaruhnya dana pendidikan terhadap laba dan aset yang ada di BUS dan UUS maupun yang ada di BPRS di Indonesia. Jika kita melihat pada besar prosentasi alokasi dana pendidikan baik yang ada di BUS dan UUS maupun yang ada di BPRS penulis melihat cukup besar yakni kisaran rata-rata 38\% setiap tahun nya. Jika kita melihat pada Peraturan Bank Indonesia (PBI) pasal 5/14/PBI/2003 dijelaskan bahwa besar dana pendidikan yang harus disediakan adalah sebesar $5 \%$ dari Anggaran Pengeluaran Sumber Daya Manusia, maka dengan alokasi dana pendidikan dengan kisaran 38\% setiap tahunnya tidak memeliki pengaruh yang bisa meningkatkan perolehan laba dan aset yang dimiliki oleh BUS dan UUS maupun BPRS. Pada dasarnya memang alokasi dana pendidikan tidak bisa berpengaruh secara langsung terhadap perolehan laba dan peningkatan jumlah aset yang didapatkan BUS dan UUS maupun 
BPRS. Adanya kegiatan pendidikan dan pelatihan lebih dimaksudkan untuk meningkatkan kualitas Sumber Daya Manusia, dan memaksimalkan pelayanan terhadap nasabah, walaupun memang pada akhirnya peningkatan pelayanan terhaadap nasabah akan meningkatkan kepercayaan dan kepuasan nasabah dan secara linear akan meningkatkan keuntungan yang diperoleh BUS dan UUS maupun BPRS, namun pengaruh atau dampak tersebut tidak secara langsung berdampak pada laba dan aset BUS atau UUS dan BPRS.

\section{PENUTUP}

Simpulan. Berdasarkan hasil penelitian yang penulis lakukan, Biaya Pendidikan pada BUS atau UUS dan BPRS di Indonesia tidak berpengaruh signifikan terhadap Peningkatan Jumlah Aset dan Laba Pada BUS atau UUS dan BPRS di Indonesia. Apabila Biaya Pendidikan berpengaruh signifikan terhadap peningkatan jumlah aset dan laba, maka jumlah (besar, kecil) dana pendidikan akan mempengaruhi nilai (besar, kecil) aset dan laba yang diperoleh tersebut yang artinya semakin besar pembiayaan dana pendidikan maka akan semakin tinggi pula aset dan laba yang diperoleh BUS atau UUS dan BPRS di Indonesia, sebaliknya apabila Biaya Pendidikan tidak berpengaruh signifikan terhadap aset dan laba maka jumlah (besar, kecil) Biaya Pendidikan tidak akan mempengaruhi nilai (besar, kecil) Aset dan Laba yang artinya semakin tinggi biaya pendidikan, tidak meningkatkan penilaian terhadap aset dan laba pada BUS atau UUS dan BPRS tersebut.

Dengan melihat pada hasil penelitian yang menunjukan bahwa tidak adanya pengaruh biaya pendidikan terhadap peningkatan jumlah aset dan laba yang diperoleh BUS atau UUS dan BPRS, maka penulis menyarankan untuk lebih meniminalkan alokasi dana pendidikan dengan cara menyeleksi calon pegawai atau calon karyawan dengan lebih baik atau lebih selektif lagi. Sehingga BUS atau UUS dan BPRS tidak harus mengeluarkan biaya pendidikan yang lebih besar dan bisa mengalokasikan danaya untuk keperluan lain.

\section{DAFTAR PUSTAKA}

Ascarya, (2012) Akad dan Produk Bank Syariah, PT. Raja Grafindo Persada, Jakarta.

Kristin Prasetyoningrum. Ari, (2010) "Analisis Pengaruh Independensi dan Profesionalisme Dewan Pengawas Syariah terhadap Kinerja Bank Perkreditan Rakyat Syariah di Jawa Tengah", Jurnal ASET, 12 (1), Maret.

Muhammad, (2014) Manajemen Dana Bank Syariah, PT. Raja Grafindo Persada, Jakarta. Penerapan Manajemen Risiko Bagi Bank Umum, Peraturan Bank Indonesia (PBI) NO: 11/ 25 /PBI/2009 tentang perubahan atas Peraturan Bank Indonesia NO: $5 / 8 / \mathrm{PBI} / 2003$

Peraturan Bank Indonesia (PBI) NO: 9/ 17 /PBI/2007 tentang Sistem Penilaian Tingkat Kesehatan Bank Perkreditan rakyat Berdasarkan Prinsip Syariah.

Peraturan Bank Indonesia (PBI) NO: 5/14/PBI/2003, tentang Penyediaan Minimal Dana Pendidikan.

Peraturan Bank Indonesia (PBI) NO: 15/13/PBI/2013, tentang Bank Umum Syariah.

Peraturan Bank Indonesia (PBI) NO: 15/14/PBI/2013, tentang Unit Usaha Syariah.

Peraturan Bank Indonesia (PBI) NO: 11/23/PBI/2009, tentang Bank Pembiayaan Rakyat Syariah.

Prabu Manungkara.Anwar, (2013) Manajemen Sumber Daya Manusia Perusahaan, Bandung: PT. Remaja Rosdakarya. 
Rivai.Veithzal, (2011) Manajemen Sumber Daya Manusia untuk Perusahaan, Jakarta: Rajawali Pers.

Sucipto, Penilaian Kinerja Keuangan, http//www.usu.ac.id, hlm.1.

Thomson, (2000) Manajemen Sumber Daya Manusia,Jakarta: Salemba Empat.

Usman. Rachmadi, (2014) Aspek Hukum Perbankan Syariah di Indonesia, Sinar Grafika, Jakarta.

Wahyu Sukarno. Kartika, Syaichu. Muhammad, (2006) "Analisis Faktor-faktor yang Mempengaruhi Kinerja Bank Umum di Indonesia", Jurnal Studi Management dan Organisasi, 3 (2), Edisi Juli. 